\title{
Melastomataceae na RPPN do Clube Caça e Pesca Itororó, Uberlândia, MG, Brasil
}

\author{
Lucas F. Bacci ${ }^{1,3,4}$ Ana Flávia Alves Versiane' ${ }^{1}$ Ana Luiza Freitas Oliveira ${ }^{2}$ e Rosana Romero ${ }^{3}$
}

Recebido: 14.05.2016; aceito: 19.09.2016

\begin{abstract}
Melastomataceae in RPPN of the Clube Caça e Pesca Itororó, Uberlândia, Minas Gerais State, Brazil). The present study aimed to do a floristic inventory and a taxonomy treatment of Melastomataceae from the RPPN of the Clube Caça e Pesca Itororó Uberlândia, State of Minas Gerais, Brazil. We found 28 species in 12 genera. Miconia is the most diverse with eight species, followed by Microlicia (four spp.), Siphanthera (three spp.), Leandra, Rhynchanthera, Tibouchina, Trembleya (two spp. each), and Acisanthera, Cambessedesia, Desmoscelis, Lavoisiera and Macairea with one species each.
\end{abstract}

Keywords: Cerrado, Miconia, Microlicia, vereda

RESUMO - (Melastomataceae na RPPN do Clube Caça e Pesca Itororó, Uberlândia, MG, Brasil). O presente estudo teve como objetivo o inventário e tratamento taxonômico das Melastomataceae encontradas na RPPN do Clube Caça e Pesca Itororó Uberlândia, MG, Brasil. Durante o estudo foram encontradas 28 espécies distribuídas em 12 gêneros. Miconia é o gênero mais diverso com oito espécies, seguido por Microlicia (quatro spp.), Siphanthera (três spp.), Rhynchanthera, Tibouchina, Trembleya e Leandra (duas spp. cada), Acisanthera, Cambessedesia, Desmoscelis, Lavoisiera e Macairea, com apenas uma espécie cada.

Palavras-chave: Cerrado, Miconia, Microlicia, vereda

\section{Introdução}

O Cerrado ocupa aproximadamente $23 \%$ do território nacional distribuindo-se, principalmente, na região central do Brasil (Ribeiro \& Walter 2008). O bioma inclui vegetação campestre, savânica e florestal, e possui uma flora rica e diversa (Klink \& Machado 2005). Em contrapartida, o Cerrado sofre com a exploração humana, sendo classificado como um hotspot para biodiversidade (Myers et al. 2000). Asteraceae, Fabaceae, Orchidaceae, Poaceae e Melastomataceae são as principais famílias que compõem a flora deste bioma (Mendonça et al. 2008). Destaque deve ser dado à família Melastomataceae, que apresenta cerca de 490 espécies distribuídas em 34 gêneros no Cerrado, sendo 249 espécies e três gêneros endêmicos do Bioma (Baumgratz et al. 2016). Os indivíduos desta família são facilmente reconhecidos pelas folhas decussadas com venação acródroma, estames geralmente falciformes e anteras poricidas (Romero \& Martins 2002).

A flora e a fauna da Reserva do Clube Caça e Pesca Itororó Uberlândia (CCPIU) vem sendo intensamente investigada nos últimos anos sob vários aspectos, podendo ser citados os estudos de inventário das veredas (Araújo et al. 2002), de germinação (Carvalho et al. 2005), biologia floral (Santos et al. 1997, Consolaro et al. 2005, Araújo \& Oliveira 2007, Araújo et al. 2011), plasticidade e variação fenotípica (Fuzeto \& Lomônaco 2000, Cardoso \& Lomônaco 2003, Rocha Filho \& Lomônaco 2006) e ecologia de populações (Del-Claro et al. 2002, Alvarenga et al. 2007, Augusto \& Garófalo 2007). Contudo, até o momento, nenhum estudo taxonômico sobre as famílias mais ricas de Angiospermas foi feito na área. Assim, o presente estudo pretende

1. Universidade Estadual de Campinas, Departamento de Biologia Vegetal, Av. Bertrand Russel s.n., Cidade Universitária Zeferino Vaz, 13083-970 Campinas, SP, Brasil

2. Universidade Estadual Paulista, Instituto de Biociências, Avenida 24 A,1.515, Campus Rio Claro, 13506-900 Rio Claro, São Paulo, Brasil

3. Universidade Federal de Uberlândia, Instituto de Biologia, Rua Ceará s.n., Campus Umuarama, 38400-902 Uberlândia, Minas Gerais, Brasil

4. Autor para correspondência: lucasfbacci@gmail.com 
contribuir para o conhecimento das Melastomataceae no Cerrado, fornecendo chave para identificação das espécies, descrições morfológicas, bem como dados de ocorrência na área de estudo e de floração e frutificação das espécies.

\section{Material e métodos}

Área de estudo - O Clube Caça e Pesca Itororó Uberlândia está situado a $5 \mathrm{~km}$ oeste do centro de Uberlândia $\left(18^{\circ} 59^{\prime} \mathrm{S}, 48^{\circ} 18^{\prime} \mathrm{W}\right)$ abrangendo 640 hectares. Em seu interior abriga uma área que, devido à sua biodiversidade e boa conservação, foi declarada como Reserva Particular do Patrimônio Natural (RPPN) pelo Instituto Brasileiro do Meio Ambiente (IBAMA) em 1992. A RPPN possui 127 hectares e é dividida em duas fitofisionomias principais: o cerrado (sentido restrito) e o campo sujo (densa vegetação rasteira e presença de arbustos e árvores bem esparsas) que são transpassados por uma vereda, além de duas pequenas manchas de mata (Apolinário \& Schiavini 2002, figura 1). A vereda caracteriza-se como uma rede de drenagem superficial que forma pequenas valas de exposição do lençol freático, alterando sua vazão ao longo do ano (Boaventura 1978). É uma unidade vegetacional composta por três tipos de vegetação diferentes que se organizam paralelamente: campo úmido, campo limpo (Brejo Permanente Graminoso) e buritizal (Eiten 2001). Apesar dessa composição, as transições entre as faixas nem sempre são claras e formam, às vezes, um componente arbustivo sob os buritis (Mauritia flexuosa L. f.), definido como comunidades vegetais hidrófilas (Ribeiro \& Walter 1998, Eiten 2001).

Tratamento taxonômico - As descrições morfológicas foram baseadas em aproximadamente 310 exsicatas de Melastomataceae depositadas no herbário HUFU (sigla de acordo com Thiers 2015, continuamente atualizado), que correspondem às coletas feitas nos últimos 20 anos e nas coleções feitas quinzenalmente nos anos de 2011 e 2012 pelos autores. A análise dos espécimes foi elaborada com auxílio de estereomicroscópio e as medidas tomadas em paquímetro digital. A caracterização morfológica das estruturas reprodutivas e vegetativas seguiu Radford et al. (1974), enquanto do indumento seguiu Wurdack (1986). Apenas um espécime por espécie foi citado em "material selecionado", enquanto os demais materiais examinados foram relacionados na lista de exsicatas ao final do artigo. A chave de identificação para as espécies, bem como as descrições foram realizadas com base em caracteres diagnósticos do material examinado. Dados de floração e frutificação foram obtidos das etiquetas contidas nas exsicatas e das observações no campo. Imagens das espécies de Melastomataceae do Clube e Caça estão disponíveis em Bacci et al. (2016).

\section{Resultados e Discussão}

Melastomataceae Juss., Gen. P1. 328. 1789.

Ervas, subarbustos, arbustos ou árvores. Ramos glabros ou revestidos por indumento variado. Folhas sésseis a pecioladas, simples, opostas, às vezes dispostas em braquiblastos, nervuras acródromas basais ou suprabasais. Tirsos ou flores isoladas; laterais ou terminais. Flores 4-6 meras, sésseis ou pediceladas; pétalas alvas, róseas, arroxeadas ou alaranjadas de base amarela; sépalas persistentes ou caducas; 4-12 estames, isomórficos, subisomórficos ou dimórficos, às vezes com estaminódios; filetes glabros ou pilosos; anteras com ápice truncado, atenuado ou rostrado, deiscentes por 1 ou 4 poros apicais; conectivo prolongado ou não abaixo das tecas, inapendiculado ou com apêndice ventral e/ou dorsal; ovário 2-6-locular, glabro ou piloso, estilete glabro ou piloso. Cápsula ou baga.

Melastomataceae possui 28 espécies distribuídas em 12 gêneros, ocorrendo em todas as fitofisionomias da Reserva do CCPIU, principalmente em vereda, campo limpo, campo sujo e campo úmido. O gênero mais diverso na área é Miconia Ruiz \& Pav. com oito espécies, seguido de Microlicia D. Don com quatro e Siphanthera Pohl. ex DC. com três. Leandra Raddi, Rhynchanthera DC., Tibouchina Aubl. e Trembleya DC. apresentam duas espécies cada, enquanto Acisanthera P. Browne, Cambessedesia DC., Desmoscelis Naudin, Lavoisiera DC. e Macairea DC. apresentam uma espécie. Algumas espécies estão restritas à vereda e ao campo úmido (Acisanthera variabilis (DC.) Triana, Lavoisiera grandiflora Naudin, Miconia chamissois Naudin, M. theizans (Bonpl.) Cogn., Microlicia cordata (Spreng.) Cham., M. helvola (Spreng.) Triana, Siphanthera foliosa (Naudin) Wurdack, Tibouchina candolleana Cogn. e Trembleya phlogiformis DC., enquanto Miconia leucocarpa DC. e M. ferruginata DC. ocorrem apenas no cerrado sentido restrito. Duas novas espécies do gênero Microlicia, não incluídas no trabalho, são novidades taxonômicas e o manuscrito com suas descrições está em fase de redação. 
Chave para identificação das espécies de Melastomataceae da Reserva do Clube Caça

e Pesca Itororó Uberlândia, Minas Gerais

1. Estames em número igual ao das pétalas

2. Subarbustos a arbustos; flores 5-meras; ovário 3-5 locular

3. Estames subisomórficos

20. Rhynchanthera dichotoma

3. Estames dimórficos, com um deles muito maior que os demais 21. Rhynchanthera grandiflora

2. Ervas; flores 4-meras; ovário 2-locular

4. Flores em glomérulos; anteras com ápice rostrado; ausência de estaminódios

22. Siphanthera cordata

4. Flores em dicásios; anteras com ápice truncado; presença de estaminódios

5. Folhas lineares 23. Siphanthera foliosa

5. Folhas ovais 24. Siphanthera gracillima

1. Estames em número duplo ao das pétalas

6. Anteras com ápice rostrado

7. Flores 6-meras; cápsula deiscente da base para o ápice

4. Lavoisiera grandiflora

7. Flores 5-meras, cápsula deiscente do ápice para a base

8. Ovário 3-locular

9. Anteras tetraesporangiadas

10. Folhas cordadas; folhas do ramo principal maiores que as dos ramos laterais; frutos arredondados 16. Microlicia cordata

10. Folhas lanceoladas; todas as folhas do mesmo tamanho; frutos ovais ...... 19. Microlicia polystemma

9. Anteras poliesporangiadas

11. Indumento viloso, folhas glaucas; hipanto campanulado

17. Microlicia fasciculata

11. Indumento hirsuto, folhas verdes a verde-amareladas; hipanto urceolado 18. Microlicia helvola

8. Ovário 5-locular

12. Indumento constituído de tricomas glandulares curto-pedunculados; margem foliar revoluta; flores curto-pediceladas (1-2 mm compr.) 27. Trembleya parviflora

12. Indumento constituído de tricomas glandulares longo-pedunculados; margem foliar não revoluta; flores longo-pediceladas (6-9 mm compr.)

28. Trembleya phlogiformis

6. Anteras com ápice atenuado ou truncado, nunca rostrado

13. Fruto cápsula

14. Pétalas vermelho-alaranjadas de base amarela

2. Cambessedesia hilariana

14. Pétalas inteiramente róseas, róseas com a base branca ou arroxeadas

15. Ápice do ovário glabro 1. Acisanthera variabilis

15. Ápice do ovário revestido por tricomas

16. Estames dimórficos

17. Flores 4-meras; filetes com tricomas glandulares na face ventral 7. Macairea radula

17. Flores 5-meras; filetes glabros 3. Desmoscelis villosa

16. Estames subisomórficos

18. Subarbustos; filetes e apêndice ventral glabros 26. Tibouchina gracilis

18. Árvores ou arvoretas; filetes e apêndice ventral glandulosos ... 25. Tibouchina candolleana

13. Fruto baga

19. Pétalas com ápice agudo

20. Folhas ovais a lanceoladas; tirsos com ramos dicasiais; estames róseos; conectivo prolongado abaixo das tecas 5. Leandra aurea

20. Folhas arredondadas a cordadas; tirsos com ramos congestos; estames brancos; conectivo não prolongado abaixo das tecas 6. Leandra erostrata

19. Pétalas com ápice obtuso, retuso ou arredondado

21. Tirsos com ramos secundifloros ou glomerulados 22. Folhas sésseis a subsésseis; margem das pétalas ciliado-glandulosa 22. Folhas pecioladas; margem das pétalas glabra 10. Miconia fallax 
23. Face abaxial da folha revestida por indumento aracnóide canescente .... 8. Miconia albicans

23. Face abaxial da folha revestida por tricomas estrelados ou estrelado-furfuráceos

24. Lâmina foliar elíptico-lanceolada a lanceolada, margem inteira a levemente sinuosa; tirsos $12-26 \mathrm{~cm}$ compr. 11. Miconia ferruginata

24. Lâmina foliar oval a elíptica, margem inteira a denteado-ciliada; tirsos ca. $7 \mathrm{~mm}$ compr. 12. Miconia leucocarpa

21. Tirsos com ramos dicasiais

25. Anteras 4-poradas

15. Miconia theizans

25. Anteras uniporadas

26. Hipanto externamente glabro

27. Conectivo prolongado abaixo das tecas, apêndice ventral biauriculado, calcarado no dorso ou com aurículas e calcar fundidos formando uma projeção basal contínua 9. Miconia chamissois

27. Conectivo não prolongado abaixo das tecas, apenas um calcar dorsal 13. Miconia ligustroides

26. Hipanto externamente com indumento estrelado-furfuráceo ou apenas estrelado

14. Miconia rubiginosa

1. Acisanthera variabilis (DC.) Triana, Trans. Linn. Soc. London 28 (1): 34 (1871).

Subarbustos ca. 0,5 m alt., procumbentes. Ramos, pecíolos, face abaxial das folhas, hipanto e sépalas hirsuto-glandulosos. Folhas opostas, pecioladas, pecíolos ca. $2 \mathrm{~mm}$ compr.; lâmina oval, ápice acuminado, base arredondada, margem inteira a levemente serreada, ciliada, face adaxial glabra ou com tricomas glandulares esparsos, 2 pares de nervuras basais, o mais externo inconspícuo. Tirsos terminais. Flores 5-meras; hipanto campanulado; sépalas subuladas, ápice glanduloso; pétalas róseas, oblongas, ápice arredondado, margem inteira, glabra; estames 10, lilases, dimórficos, filetes glabros, anteras subuladas, ápice atenuado, conectivo prolongado abaixo das tecas, apêndice ventral creme, bilobado; ovário 3-locular, ápice glabro, estilete glabro. Cápsula.

Material selecionado: 17-V-2012, fl., L.F. Bacci et al. 22 (HUFU).

$\mathrm{Na}$ Reserva é encontrada somente na borda de vereda, em local inundado. Floresce em maio, junho e agosto e frutifica em novembro. Reconhecida pelo hábito procumbente, pétalas e estames lilases e apêndice ventral do conectivo bilobado.

2. Cambessedesia hilariana (Kunth.) DC., Prodr. 3 : 111 (1828).

Subarbustos 0,1-0,3 m alt., comumente prostrados. Ramos, folhas e hipanto glandulosos. Folhas opostas ou em fascículos, sésseis ou curto pecioladas, até 2 mm compr.; lâmina oval a oval-lanceolada, ápice agudo, base atenuada, margem denteada, 1-2 pares de nervuras basais. Flores isoladas, axilares ou terminais. Flores 5-meras; hipanto campanulado, com emergências glandulosas; sépalas cordiformes, glabras; pétalas vermelho-alaranjadas com base amarela, oblongas, ápice acuminado, margem inteira, glabra; estames 10, amarelos, subisomórficos, anteras subuladas, ápice truncado, conectivo não prolongado abaixo das tecas, espessado no dorso, inapendiculado ventralmente; ovário 5-locular, ápice com tricomas glandulares. Cápsula.

Material selecionado: 15-II-2011, fl., R. Romero et al. 8435 (HUFU).

Na Reserva é comumente encontrada em solo arenoso na transição entre o cerrado sentido restrito e a vereda. Floresce e frutifica de outubro a maio. A espécie é reconhecida pelo hábito diminuto, ramos, folhas e hipanto recobertos por tricomas glandulosopedunculados e flores vistosas com pétalas vermelhoalaranjadas na metade superior e amarelas na metade inferior.

3. Desmoscelis villosa (Aubl.) Naudin, Ann. Sci. Nat., ser. 3, Bot; 13: 30 (1849).

Subarbustos 0,3-1 m alt., eretos. Ramos, hipanto e sépalas densamente seríceo-vilosos às vezes, entremeados por tricomas setoso-glandulares. Folhas pecioladas, pecíolos 1-6 mm compr.; lâmina elíptica, ápice agudo a acuminado, base arredondada, margem inteira, 2-3 pares de nervuras basais. Tirsos com ramos dicasiais, 15-20 cm compr., terminais. Flores 5-meras; hipanto oblongo; sépalas triangulares, ápice agudo, margem inteira; pétalas róseas, obovais a oblongo- 
obovais, ápice arredondado, margem inteira; estames 10, dimórficos, filetes glabros, anteras subuladas, ápice truncado, conectivo prolongado abaixo das tecas, anteras do ciclo antessépalo róseas, apêndice ventral do conectivo biauriculado, anteras do ciclo antepétalo amarelas, apêndice ventral do conectivo bilobado; ovário 5-locular, ápice com tricomas setosos. Cápsula.

Material selecionado: 26-V-2011, fl., A.F.A. Versiane \& L.F. Bacci 13 (HUFU).

$\mathrm{Na}$ Reserva é encontrada somente em campo úmido. Floresce e frutifica de março a outubro. Reconhecida por apresentar indumento densamente seríceo-viloso nos ramos, folhas, hipanto e sépalas, e conectivo dos estames antessépalos com apêndice ventral longamente biauriculado e dos estames antepétalos bilobado.

4. Lavoisiera grandiflora Naudin, Ann. Sci. Nat., Bot. Ser. 3, 2: 148 (1844).

Subarbustos ou arbustos 0,5-2,5 m alt., eretos. Ramificações dicotômicas e tricotômicas a partir da metade superior do caule. Ramos cilíndricos com cicatrizes foliares hirsuto-glandulosas. Folhas opostas, sésseis; lâmina oblonga, ápice acuminado, base arredondada, margem inteira, glabra, 3 pares de nervuras basais, par marginal inconspícuo, nervura principal calosa. Flores solitárias, 6-meras, pedicelo 6-10 mm compr.; hipanto oblongo, glabro; sépalas triangulares, glabras; pétalas lilases, obovais, ápice arredondado a retuso, margem inteira; estames 12, amarelos, dimórficos, filetes glabros, anteras oblongas, ápice rostrado, rostro ca. $0,5 \mathrm{~mm}$, conectivo prolongado abaixo das tecas, apêndice ventral bilobado; ovário 6-locular, ápice glabro; estilete amarelo, glabro. Cápsula loculicida, deiscente da base para o ápice.

Material selecionado: 17-VII-2012, fl., L.F. Bacci et al. 17 (HUFU).

$\mathrm{Na}$ Reserva é encontrada em borda da vereda. Floresce em janeiro, maio, junho e julho. Facilmente reconhecida pelas flores vistosas com seis pétalas e frutos do tipo cápsula, deiscentes da base para o ápice.

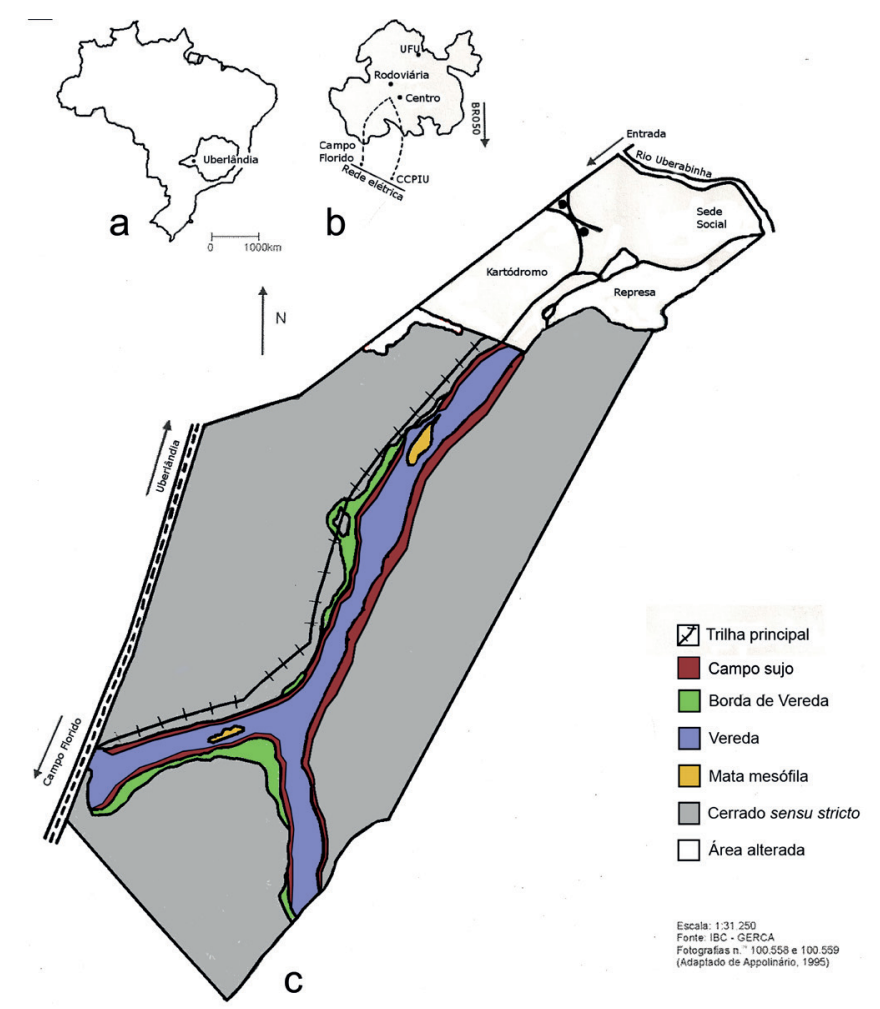

Figura 1. a. Localização do município de Uberlândia no Estado de Minas Gerais, Brasil. b. Localização do Clube Caça e Pesca Itororó de Uberlândia, Minas Gerais, Brasil (CCPIU). c. Distribuição das fitofisionomias na Reserva. Modificado de Apolinário (1995).

Figure 1. a. Location of the municipality of Uberlândia in the state of Minas Gerais, Brazil. b. Location of the Clube Caça e Pesca Itoróró of Uberlândia, Minas Gerais, Brazil (CCPIU). c. Distribution of the vegetation types in the Reserve. Modified from Apolinário (1995). 
5. Leandra aurea (Cham.) Cogn., in Mart., Eichler \& Urban, Fl. bras. 14(4): 142 (1886).

Arbustos ca. $2 \mathrm{~m}$ alt. Ramos cilíndricos, indumento estrelado, constituído por tricomas dendríticos. Folhas opostas, pecioladas; lâmina oval a lanceolada, ápice agudo, base arredondada, margem sutilmente denticulada, ciliada, face adaxial estrigosa, face abaxial hirsuta nas nervuras, entremeada por tricomas dendríticos, 2 pares de nervuras basais, par marginal inconspícuo. Tirsos com ramos dicasiais, 15-16 cm compr., laterais; brácteas 1,7-3 mm compr., lineares a lanceoladas. Flores 5-meras; hipanto oblongo, externamente com indumento viloso canescente entremeado por tricomas dendríticos esparsos; sépalas arredondadas, dentes externos triangulares, persistentes, indumento semelhante ao do hipanto; pétalas brancas, triangulares, ápice agudo, margem inteira, glabra; estames 10, róseos, isomórficos, filetes glabros, anteras subuladas, ápice truncado, conectivo prolongado abaixo das tecas, dorsalmente espessado; ovário 3-locular, com ápice revestido por tricomas simples. Baga globosa, imatura avermelhada a esverdeada, madura arroxeada.

Material selecionado: 17-V-2012, fl., L.F. Bacci et al. 18 (HUFU).

Encontrada nos ambientes mais secos da Reserva, em cerrado sentido restrito e na transição cerradocampo sujo. Floresce em maio e outubro e frutifica em dezembro. Reconhecida pelos tirsos com ramos dicasiais alongados, brácteas pequenas (1,7-3 mm compr.) e aos pares e conectivo prolongado abaixo das tecas, diferentemente de Leandra erostrata, que possui tirsos com ramos congestos, 3-5 brácteas maiores (3,5-5 mm compr.) que se sobrepõem e conectivo não prolongado abaixo das tecas.

6. Leandra erostrata (DC.) Cogn., in Mart., Eichler \& Urban, Fl. bras. 14 (4): 139 (1886).

Arbustos 0,8-1,5 m alt. Ramos cilíndricos, densamente hirsutos, entremeados por tricomas dendríticos. Folhas opostas, pecioladas; lâmina arredondada a cordada, ápice agudo a acuminado, base arredondada, margem inteira a crenulada, ciliada, face adaxial estrigosa, face abaxial hirsuto-tomentosa, 2 pares de nervuras basais. Tirsos com ramos congestos 5-8 cm compr., laterais; brácteas 3,5-5, oblongas. Flores 5-meras; hipanto campanulado, externamente com indumento hirsuto, canescente; cálice persistente, sépalas arredondadas, dentes externos triangulares, persistentes, indumento semelhante ao do hipanto; pétalas brancas, triangulares, ápice acuminado, margem inteira, glabra; estames 10, brancos, isomórficos, filetes glabros, anteras subuladas, ápice truncado, conectivo não prolongado abaixo das tecas, espessado na base; ovário 3-locular, com ápice revestido moderadamente por tricomas simples. Baga globosa, imatura verde, madura atropurpúrea.

Material selecionado: 17-V-2012, fl., L.F. Bacci et al. 19 (HUFU).

Encontrada em campo sujo e campo limpo. Floresce em março, maio, outubro, novembro e frutifica em dezembro. Ver comentários em L. aurea.

7. Macairea radula (Bonpl.) DC. Prodr. 3: 109 (1828).

Subarbustos ca. $1 \mathrm{~m}$ alt. Ramos, hipanto e sépalas seríceos, entremeados por tricomas glandulares, face adaxial das folhas seríceo-estrigosa, bulada, face abaxial viloso-glandulosa. Folhas opostas, pecioladas, pecíolos 0,5-2 cm compr.; lâmina elíptica, ápice arredondado a acuminado, base atenuada, margem inteira, 2 pares de nervuras, par mais interno suprabasal, mais externo basal e inconspícuo. Tirsos terminais. Flores 4-meras; hipanto campanulado; sépalas subuladas, terminando em um tricoma glandular; pétalas róseas com base creme, obovais, ápice arredondado a acuminado, margem inteira, glabra; estames 8, amarelos, dimórficos, filetes com tricomas glandulares na face ventral, anteras subuladas, ápice atenuado, no ciclo antessépalo róseas, no ciclo antepétalo amarelas, conectivo prolongado abaixo das tecas, expandido na região dorso-basal; ovário 4-locular com tricomas glandulares no ápice. Cápsula.

Material selecionado: 13-VIII-1999, fl., G.M. Araújo 2677 (HUFU).

Encontrada em vereda. Floresce e frutifica em abril, junho e agosto. Reconhecida pela superfície bulada da face adaxial da lâmina foliar, pelo par de nervuras suprabasais, inflorescências terminais, sépalas subuladas terminadas em um tricoma glanduloso e tricomas glandulares na face ventral dos filetes.

8. Miconia albicans (Sw.) Steud., Nomencl. Bot. 2: 139 (1841).

Arbustos ca. $1 \mathrm{~m}$ alt. Ramos subcilíndricos, face abaxial das folhas, inflorescência, hipanto 
e sépalas aracnóide canescente. Folhas opostas, pecioladas; lâmina ovado-lanceolada, ápice agudo a levemente acuminado, base arredondada, margem crenulada, 2 pares de nervuras basais a suprabasais, face adaxial densamente tomentosa nas folhas jovens, posteriormente glabra. Tirsos com ramos secundifloros 7-15 cm compr., terminais. Flores 5-meras; hipanto campanulado, externamente com indumento tomentoso, sépalas e dentes externos fundidos, persistente, triangulares; pétalas brancas, obovais, ápice arredondado, margem glabra; estames 10, brancos, subisomórficos, filetes glabros, anteras uniporadas, ápice truncado, conectivo curtamente prolongado abaixo das tecas, apêndice trilobado com 2 aurículas laterais proeminentes; ovário 3-locular, com ápice glabro. Baga globosa, imatura rosa, madura verde-jade.

Material selecionado: 9-IX-2011, fl., A.F.A. Versiane \& L.F. Bacci 42 (HUFU).

Encontrada, principalmente, no cerrado sentido restrito e na transição cerrado sentido restrito-campo sujo. Floresce e frutifica em setembro e outubro. Facilmente reconhecida das demais espécies de Miconia pelas folhas discolores, indumento da face abaxial aracnóide canescente e inflorescência com ramos secundifloros. É morfologicamente semelhante a M. fallax, que se diferencia por apresentar folhas sésseis a subsésseis, indumento estrelado-canescente nos ramos e face abaxial da lâmina, além das pétalas com margem ciliado-glandulosa.

9. Miconia chamissois Naudin, Ann. Sci. Nat. Bot., Ser. 3, 16: 179 (1850).

Arbustos a árvores 0,4-3,5 m alt. Ramos quadrangulares, pecíolos, face adaxial e abaxial da folha, hipanto e sépalas glabros. Folhas opostas, pecioladas; lâmina elíptica a lanceolada, ápice agudo a acuminado, base atenuada a arredondada, margem inteira, 2 pares de nervuras suprabasais, par marginal inconspícuo. Tirsos com ramos dicasiais 4,5-20 cm compr., terminais. Flores 5-meras; hipanto campanulado, externamente glabro, sépalas e dentes externos fundidos, persistentes, triangulares; pétalas brancas, obovais, ápice arredondado, margem glabra; estames 10, brancos, subisomórficos, filetes glabros, anteras uniporadas, ápice truncado, conectivo prolongado abaixo das tecas, biauriculados, calcarados no dorso ou com aurículas e calcar fundidos formando uma projeção basal contínua; ovário 3-locular, com ápice glabro. Baga globosa, imatura verde, madura arroxeada.

Material examinado: 15-II-2011, fl., R. Romero et al. 8434 (HUFU).

Abundante na vereda e em suas bordas. Floresce e frutifica de dezembro a julho. Reconhecida pelas estruturas reprodutivas e vegetativas glabras, folhas com par de nervuras suprabasais e inflorescências terminais vistosas.

\section{Miconia fallax DC., Prodr. 3: 181 (1828).}

Subarbustos a arbustos 0,6-2 m alt. Ramos, pecíolos, face abaxial das folhas, hipanto e sépalas estrelado-canescentes. Folhas opostas, sésseis a subsésseis; lâmina oval a oval-lanceolada, ápice arredondado, raro agudo, base arredondada a cordada, margem levemente crenada, 2 pares de nervuras basais, face adaxial glabra. Tirsos com ramos secundifloros 6-14 cm compr., terminais. Flores 5-meras, hipanto campanulado; sépalas e dentes externos fundidos, persistentes, triangulares; pétalas brancas, obovais, ápice arredondado, margem ciliado-glandulosa; estames 10, brancos, subisomórficos, filetes glabros, anteras uniporadas, ápice truncado, conectivo prolongado abaixo das tecas, espessado no dorso e calcarado na base; ovário 3-locular, com ápice glabro. Baga globosa, imatura verde, madura atropurpúrea.

Material selecionado: 9-IX-2011, fl., A.F.A. Versiane \& L.F. Bacci 41 (HUFU).

Abundante em ambientes mais secos, como cerrado sentido restrito e campo sujo. Floresce em fevereiro, maio, setembro e outubro e frutifica em setembro, outubro e novembro. Caracteriza-se pelo hábito arbustivo ou subarbustivo, folhas discolores, sésseis ou subsésseis com indumento estreladocanescente na face abaxial, pétalas com margem ciliada e antera com conectivo levemente espessado no dorso. Ver comentários em M. albicans.

\section{Miconia ferruginata DC., Prodr. 3: 181 (1828).}

Arbustos a árvores 1,5-4 m alt. Ramos robustos, espessados, revestidos por tricomas estreladoocráceos. Folhas opostas, pecioladas; lâmina elípticolanceolada a lanceolada, ápice agudo a levemente acuminado, base arredondada a subcordada, margem inteira a levemente sinuosa; 2 pares de nervuras basais, ambas as faces da lâmina estrelado-ocráceas, face adaxial glabrescente. Tirsos com ramos secundifloros 12-26 cm compr., terminais. Flores 5-meras, hipanto 
campanulado, externamente com tricomas estrelados ocráceos; sépalas triangulares, dentes externos inconspícuos, persistentes; pétalas brancas, obovais, ápice arredondado, margem glabra; estames 10, brancos, filete glabro, anteras uniporadas, ápice truncado, conectivo prolongado abaixo das tecas, espessado dorsalmente e com dois apêndices ventrais; ovário 3-locular, com ápice glabro. Baga globosa, imatura verde, madura enegrecida.

Material selecionado: Perdizes, 16-V-2002, fl., $R$. Arruda et al. 31 (HUFU).

Ocorre exclusivamente em cerrado sentido restrito, raramente encontrada na Reserva, nunca fértil. Floresce e frutifica em maio, junho, julho e outubro. Reconhecida pelos ramos robustos, espessados e rugosos, estrelado-ocráceos, folhas discolores e inflorescências com ramos secundifloros.

\section{Miconia leucocarpa DC., Prodr. 3: 182 (1828).}

Árvores 2,5-4 m alt. Ramos cilíndricos, pecíolos, face abaxial das folhas, hipanto (externamente) e sépalas do cálice densamente estrelado-furfuráceos. Folhas opostas, pecioladas; lâmina oval a elíptica, ápice agudo, raro mucronado, base arredondada a cordada, margem inteira a denteado-ciliada, 2 pares de nervuras basais. Tirsos com ramos glomerulados ca. $7 \mathrm{~cm}$ compr., terminais. Flores 5-meras; hipanto campanulado, sépalas e dentes externos fundidos, persistentes, triangulares; pétalas brancas, obovais, ápice arredondado, margem glabra; estames 10 , brancos, isomórficos, filetes glabros, anteras uniporadas, ápice truncado, conectivo prolongado abaixo das tecas, apêndice com dois lobos ventrais e um calcar curto dorsal; ovário 3-locular, com ápice glabro. Baga globosa, imatura amarela, madura arroxeada.

Material selecionado: 14-IV-1994, b. fl., R. Romero \& J.N. Nakajima 799 (HUFU).

Poucos indivíduos ocorrem exclusivamente em cerrado sentido restrito. Floresce e frutifica em abril e maio. O nome Miconia pohliana Cogn. é comumente citado em trabalhos de flora, contudo este basiônimo foi sinonimizado sob M. leucocarpa por Goldenberg \& Martin (2008). A espécie caracteriza-se pelo indumento estrelado-furfuráceo ocráceo na face abaxial da folha, que se destaca facilmente ao toque. A coloração ocrácea separa facilmente esta espécie de M. rubiginosa, que também ocorre na área de estudo, e que apresenta indumento estrelado-ferrugíneo.
13. Miconia ligustroides (DC.) Naudin, Ann. Sci. Nat., Bot., sér. 3 16: 167 (1850).

Arbusto a arvoreta 1-2,5 m alt. Ramos, pecíolos, face abaxial das folhas, hipanto e sépalas glabros. Folhas opostas, pecioladas; lâmina elíptica, ápice acuminado, base arredondada, margem inteira, levemente revoluta, 2 pares de nervuras basais, face adaxial glabra. Tirsos com ramos dicasiais 6-12 cm compr., terminais. Flores 5-meras; hipanto campanulado, glabro, sépalas arredondadas, dentes externos reduzidos, caducos; pétalas brancas, obovais, ápice arredondado, margem glabra; estames 10 , isomórficos, filetes glabros, anteras uniporadas, ápice truncado, conectivo não prolongado abaixo das tecas, com calcar dorsal; ovário 3-locular, com ápice glabro. Baga globosa, imatura verde, madura enegrecida.

Material selecionado: 22-X-1993,fl., R. Romero et al. 520 (HUFU).

Ocorre em ambientes mais secos, principalmente, na transição cerrado sentido restrito-campo sujo. Floresce de outubro a dezembro e frutifica de fevereiro a maio. A espécie caracteriza-se pelos ramos e face abaxial da lâmina foliar com tricomas estrelados caducos, hipanto glabro e cálice caduco.

\section{Miconia rubiginosa (Bonpl.) DC., Prodr. 3: 183} (1828).

Arbustos ou árvores 1,5-3 m alt. Ramos, pecíolos, face abaxial das folhas, hipanto e sépalas estrelado-ferrugíneos. Folhas opostas, pecioladas; lâmina elíptica a levemente lanceolada, ápice agudo a acuminado, base arredondada, margem inteira, 2 pares de nervuras basais, face abaxial densamente estrelada, com tricomas tricomas dendríticos e estrelados ferrugíneos. Tirsos com ramos dicasiais 8-17 cm compr., terminais. Flores 5-meras; hipanto campanulado sépalas triangulares, dentes externos inconspícuos, caducos; pétalas brancas, obovais, ápice arredondado, margem ciliado-glandulosa na metade superior; estames 10, brancos, isomórficos, filetes glabros, anteras uniporadas, ápice truncado, conectivo prolongado abaixo das tecas, apêndice com 2 aurículas ventrais curtas e um calcar no dorso ou trilobado na base; ovário 3-locular, com ápice glabro. Baga globosa, imatura verde, madura arroxeada.

Material selecionado: 6-IV-2011, fl., A.F.A. Versiane \& L.F. Bacci 11 (HUFU).

Encontrada, frequentemente, em cerrado sentido restrito. Floresce em outubro, janeiro e abril e frutifica 
em fevereiro, junho e novembro. Caracteriza-se pelas folhas discolores, e assim como os ramos, recobertas densamente por indumento estrelado-ferrugíneo.

\section{Miconia theizans (Bonpl.) Cogn., in Mart., Eichler} \& Urban, Fl. bras. 14 (4): 419 (1888).

Árvores 1,2-4 m alt. Ramos cilíndricos, hirsutos. Folhas opostas, pecioladas; lâmina oboval a elíptica, ápice acuminado, base arredondada, atenuada, raro truncada, margem serreada, 2 pares de nervuras basais, face adaxial glabra, face abaxial esparsamente glandulosa. Tirsos com ramos dicasiais 4-9 cm compr., terminais. Flores 5-meras; hipanto campanulado, glabro, sépalas inconspícuas, dentes externos, persistentes, triangulares; pétalas brancas, arredondadas, margem glabra; estames 10, brancos, isomórficos, filetes glabros, anteras 4-poradas, ápice truncado, conectivo prolongado abaixo das tecas, bituberculado ventralmente; ovário 3-locular, com ápice glabro. Baga globosa, imatura verde, madura atropurpúrea.

Material selecionado: 1-XI-2011, A.F.A. Versiane 58 (HUFU).

Comumente encontrada em vereda ou em suas bordas. Floresce e frutifica em maio, outubro, novembro e dezembro. Facilmente reconhecida pelas folhas concolores com margem serreada, ápice dos ramos avermelhados e anteras deiscentes por quatro poros apicais.

16. Microlicia cordata (Spreng.) Cham., Linnaea 9: 390 (1834).

Arbustos ca. 0,8 m alt., eretos. Ramos, folhas, hipanto e sépalas hirsutos, entremeados por tricomas glandulares curto pedunculados. Folhas esverdeadas, sésseis, do ramo principal maiores que as dos ramos laterais; lâmina oval, ápice agudo, base cordada, margem levemente serreada, 1-2 pares de nervuras basais. Flores solitárias, axilares ou terminais, 5-meras, longo pediceladas, pedicelo 1-3 mm compr.; hipanto campanulado; sépalas triangulares, ápice acuminado, de mesmo comprimento que o hipanto; pétalas róseas, oblongas, ápice agudo, margem inteira; estames 10 , dimórficos, anteras tetraesporangiadas, ápice rostrado, rostro ca. 0,2 mm compr., conectivo prolongado abaixo das tecas, anteras do ciclo antessépalo róseas, apêndice ventral do conectivo amarelo, truncado, anteras do ciclo antepétalo amarelas, apêndice ventral do conectivo amarelo, obtuso; ovário 3-locular, glabro; estilete glabro. Cápsula arredondada, deiscente do ápice para a base, ovário maduro revestido pelo hipanto.

Material selecionado: 12-VII-2011, fl., A.F.A. Versiane et al. 27 (HUFU).

Encontrada em borda de vereda, em solo hidromórfico. Floresce de novembro a abril e frutifica em março, abril, junho e julho. Reconhecida pela associação das seguintes características: folhas do ramo principal maiores do que aquelas dos ramos laterais, lâmina foliar com base cordada, flores longopediceladas e anteras tetraesporangiadas.

17. Microlicia fasciculata Mart. ex Naudin, Nova genera et species plantarum 3: 105 (1820).

Subarbustos ou arbustos 0,2-0,4 m alt., eretos. Ramos, folhas, hipanto e sépalas densamente vilosos, glaucos, entremeados por tricomas glandulares curto pedunculados. Folhas glaucas, sésseis; lâmina lanceolada, ápice agudo, base arredondada, margem inteira, 1 par de nervuras basais. Flores solitárias, axilares ou terminais, 5-meras, pediceladas, pedicelos até $2 \mathrm{~mm}$ compr.; hipanto campanulado; sépalas triangulares, ápice acuminado, longo-apiculado, menor que o comprimento do hipanto; pétalas róseas, obovais, ápice arredondado, margem ciliado-glandulosa; estames 10, dimórficos, anteras poliesporangiadas, ápice rostrado, conectivo prolongado abaixo das tecas, anteras do ciclo antessépalo róseas, rostro ca. $1 \mathrm{~mm}$ compr., apêndice ventral do conectivo amarelo, truncado, anteras do ciclo antepétalo amarelas, rostro ca. 0,6 mm compr., conectivo apenas articulado ao filete; ovário 3-locular, glabro; estilete glabro. Cápsula oval a oval-oblonga, deiscente do ápice para a base, com ovário maduro crescendo $2-3$ vezes mais que o hipanto.

Material selecionado: 17-V-2012, fl., L.F. Bacci et al. 20 (HUFU).

Encontrada na transição entre a vereda e o cerrado sentido restrito, em solo arenoso. Floresce de outubro a maio e frutifica em junho. Reconhecida pelos ramos, folhas, hipanto e sépalas com indumento denso viloso, folhas de coloração glauca, anteras poliesporangiadas e fruto com crescimento 2-3 vezes além do hipanto.

18. Microlicia helvola (Spreng.) Triana. Trans. Linn. Soc. London 28: 25 (1871).

Subarbustos ou arbustos $0,7-1 \mathrm{~m}$ alt., eretos. Ramos, folhas, hipanto e sépalas hirsutos, entremeado por tricomas glandulares curto pedunculados. Folhas 
verdes a verde-amareladas, sésseis a subsésseis, pecíolo até $0,8 \mathrm{~mm}$ compr.; lâmina oval a ovaloblonga, ápice agudo, base arredondada, margem levemente serreada, 2 pares de nervuras basais. Flores solitárias, axilares ou terminais, 5-meras, pediceladas, pedicelo 0,7-1,5 mm compr.; hipanto urceolado; sépalas triangulares, ápice acuminado, menor que o comprimento do hipanto; pétalas róseas, obovais, ápice apiculado, margem inteira; estames 10, dimórficos, anteras poliesporangiadas, ápice rostrado, conectivo prolongado abaixo das tecas, apêndice ventral do conectivo amarelo, levemente bilobado, anteras do ciclo antessépalo róseas, rostro 0,2-0,3 mm compr., anteras do ciclo antepétalo amarelas, rostro 0,1-0,2 mm compr ovário 3-locular, glabro; estilete glabro. Cápsula arredondada, deiscente do ápice para a base, com ovário maduro crescendo 2-3 vezes mais que o comprimento do hipanto, superfície rugosa.

Material selecionado: 1-IX-2011, fl., A.F.A. Versiane et al. 40 (HUFU).

Encontrada em vereda, em solo hidromórfico e na transição cerrado sentido restrito-campo limpo, em solo arenoso. Floresce e frutifica em janeiro, fevereiro e agosto. Reconhecida pelas folhas ovais a ovaloblongas com nervuras evidentes, hipanto urceolado, geralmente nigrescente, anteras poliesporangiadas, e frutos crescendo mais de duas vezes o comprimento do hipanto. Quando em material seco as folhas podem apresentar coloração verde a verde-amarelada.

19. Microlicia polystemma Naudin, Ann. Sci. Nat., Ser., 3 Bot. 3: 179 (1845).

Subarbustos ou arbustos 0,4-2 m alt., eretos. Ramos folhas, hipanto e sépalas hirsutos, entremeado por tricomas glandulares curto pedunculados. Folhas esverdeadas, sésseis; lâmina lanceolada, ápice agudo com tricoma setoso, base arredondada, margem inteira, ciliada, 1 par de nervuras basais. Flores solitárias, axilares ou terminais, 5-meras, pediceladas, pedicelo 2-3 mm compr.; hipanto campanulado; sépalas oval-triangulares, ápice agudo, com tricoma setoso, mesmo comprimento ou pouco menores que o hipanto; pétalas róseas, obovais, ápice apiculado, margem inteira; estames 10, amarelos, dimórficos, anteras tetraesporangiadas, às vezes, com máculas róseas, ápice rostrado, conectivo prolongado abaixo das tecas, anteras do ciclo antessépalo com rostro 0,5-1,0 mm compr., apêndice ventral truncado, do ciclo antepétalos com rostro $0,2-0,5 \mathrm{~mm}$ compr., conectivo apenas articulado ao filete; ovário 3-locular, glabro; estilete glabro. Cápsula oval, deiscente do ápice para base, ovário maduro crescendo duas vezes além do hipanto.

Material selecionado: 26-V-2011, fl., A.F.A. Versiane \& L.F. Bacci 12 (HUFU).

Encontrada em solo arenoso na transição cerrado sentido restrito-vereda. Floresce de janeiro a abril e frutifica de maio a dezembro. Extremamente variável quanto à forma e tamanho das folhas, comprimento da folha em relação ao entrenó e pela quantidade de tricomas (Romero 2000). Na Reserva, M. polystemma distingue-se das demais espécies do gênero, pelos estames inteiramente amarelos, às vezes com máculas róseas nas anteras e sépalas oval-triangulares com tricoma setoso conspícuo no ápice.

20. Rhynchanthera dichotoma (Desr.) DC., Prodr. 3: 107 (1828).

Subarbustos ou arbustos ca. 1,5 m alt., eretos. Ramos, folhas, hipanto e sépalas setoso-glandulosos. Folhas pecioladas, pecíolos 5-13 mm compr.; lâmina oval, ápice acuminado, base cordada, margem levemente serreada, face adaxial e abaxial estrigosas, 4 pares de nervuras basais. Tirso bíparo; brácteas ovais, ápice acuminado, base cordada, margem serrado-ciliolada. Flores 5-meras, pediceladas, pedicelo ca. $1 \mathrm{~mm}$ compr.; hipanto oblongo a oblongocampanulado; sépalas triangulares, ápice agudo; pétalas roxas, ovais, ápice levemente cuspidado, margem inteira; estames 5 , subisomórficos, conectivo prolongado abaixo das tecas, roxo, anteras creme, ápice rostrado, rostro 2,5-3 $\mathrm{mm}$ compr., apêndice ventral roxo, bilobado, 5 estaminódios; ovário 5-locular, glabro; estilete glabro. Cápsula loculicida, globosa.

Material selecionado: 17-V-2012, fl., L.F. Bacci et al. 23 (HUFU).

Encontrada em campo úmido. Floresce em março e setembro e frutifica em agosto e setembro. Reconhecida pelas flores grandes, vistosas com pétalas roxas e cinco estames férteis subisomórficos.

21. Rhynchanthera grandiflora (Aub1.) DC., Prodr. 3: 107 (1828).

Subarbustos ou arbustos 0,7-2 $\mathrm{m}$ alt., eretos. Ramos, folhas, hipanto, sépalas e pedicelo setosoglandulosos, nós com tricomas setosos. Folhas pecioladas, pecíolos 3-9 mm compr.; lâmina ovallanceolada a lanceolada, ápice acuminado, base 
arredondada, margem levemente serreada, 3 a 4 pares de nervuras basais. Tirso uníparo; brácteas lanceoladas, margem levemente serreada. Flores 5-meras, pediceladas; hipanto oblongo a ovaloblongo; sépalas subuladas; pétalas roxas, obovais, ápice levemente cuspidado, margem inteira; estames 5 , dimórficos, um deles muito maior que os demais, conectivo prolongado abaixo das tecas, roxo, anteras creme, ápice rostrado, rostro 2,5-3 $\mathrm{mm}$ compr., apêndice ventral roxo, truncado, 5 estaminódios; ovário 3-4-locular, glabro; estilete no ápice. Cápsula loculicida, arredondada.

Material selecionado: 21-III-2011, fl., A.F.A. Versiane et al. 3 (HUFU).

Ocorre em locais úmidos, podendo estar ou não associado a veredas. Floresce e frutifica de janeiro a dezembro. Possui grande variação no indumento e na forma das folhas, resultando em um grande número de sinônimos para a espécie (Renner 1990). Rhynchanthera grandiflora apresenta flores grandes, vistosas com corola arroxeada e androceu bem característico, com quatro estames iguais e um maior que os demais.

22. Siphanthera cordata Pohl ex DC., Prodr. 3: 121 (1828).

Ervas, 20-40 cm alt. Ramos, folhas, brácteas, hipanto e sépalas com tricomas glandulares pedicelados. Folhas subsésseis a pecioladas, pecíolo até $3 \mathrm{~mm}$ compr.; lâmina cordada, ápice agudo, base arredondada, margem denteada, 2 pares de nervuras basais. Dicásios terminais ou axilares, glomerifomes; Flores 4-meras, pedicelo ca. 0,3 mm compr.; hipanto oblongo-campanulado; sépalas triangulares, ápice acuminado; pétalas violáceas, obovais e levemente unguiculadas, ápice retuso, margem inteira com tricomas glandulares; estames 4, arroxeados, isomórficos, filetes glabros, anteras rostradas, rostro 1-1,5 mm compr., conectivo prolongado abaixo das tecas, apêndice ventral bilobado; ovário 2-locular, estilete creme a arroxeado, glabro. Cápsula deiscente do ápice para a base.

Material selecionado: 26-V-2011, fl., A.F.A. Versiane \& L.F. Bacci 18 (HUFU).

Ocorre na transição campo úmido-campo sujo. Floresce em abril, maio, junho e novembro e frutifica em maio. Das três espécies de Siphanthera ocorrentes na Reserva, $S$. cordata é a única com ápice da antera distintamente rostrado e inflorescência em dicásio formando glomérulos.

23. Siphanthera foliosa (Naudin) Wurdack, Mem. New York Bot. Gard. 10 (1): 97 (1958).

Ervas $20-40 \mathrm{~cm}$ alt., eretas. Ramos, hipanto e sépalas com indumento piloso-glanduloso, avermelhado. Folhas sésseis; lâmina linear, ápice agudo, margem inteira e no ápice levemente denteada, ambas as faces glabras, 2 pares de nervuras basais. Tirsos terminais, multifloras; flores 4-meras, pedicelo 1,5-3 mm compr., hipanto campanulado; sépalas triangulares, ápice acuminado; pétalas lilases, obovais, ápice arredondado, margem inteira, glabras; estames 4, arroxeados, dimórficos, filetes glabros, anteras truncadas, conectivo prolongado abaixo das tecas, apêndice ventral bilobado; 4 estaminódios, 0,5-1 mm compr.; ovário 2-locular, estilete creme a arroxeado. Cápsula deiscente do ápice para a base.

Material selecionado: 13-VIII-1993, fl., J.N. Nakajima et al. 115 (HUFU).

Encontrada em solo encharcado de veredas. Segundo Romero (1997), foram encontradas apenas duas coletas para o Estado de Minas Gerais, uma na Reserva do Clube Caça e Pesca Itororó e outra na Serra do Cabral. Floresce em julho e agosto e frutifica em agosto. Siphanthera foliosa diferencia-se de $S$. cordata e $S$. gracillima, principalmente por apresentar folhas lineares, peças florais e vegetativas em tons avermelhados e oito estames.

24. Siphanthera gracillima (Naudin) Wurdack, County Mus. Contrib. Sci. 28: 8 (1959).

Ervas 10-20 cm alt. Ramos, folhas, hipanto e sépalas com indumento glanduloso. Folhas sésseis; lâmina oval, ápice agudo, base arredondada, margem serreada, 2 pares de nervuras basais. Dicásios terminais ou laterais; flores 4-meras, pedicelo 0,5-1 mm compr.; flores 4-meras, hipanto oval a campanulado; sépalas triangulares, ápice agudo a acuminado, margem inteira; pétalas róseas, obovais, ápice arredondado, margem inteira; estames 4, arroxeados, isomórficos, filetes glabros, anteras truncadas, conectivo prolongado abaixo das tecas, apêndice ventral bilobado, 4 estaminódios, 1-2 mm compr.; ovário 2-locular, estilete creme. Cápsula deiscente do ápice para a base.

Material selecionado: 31-V-1995, fl., R. Romero \& J.N. Nakajima 2341 (HUFU). 
Encontrados poucos indivíduos em áreas de campo úmido. Floresce e frutifica de abril a agosto. Prontamente reconhecida por apresentar quatro estames, quatro estaminódios e anteras com ápice truncado.

25. Tibouchina candolleana (Mart. ex DC.) Cogn., in Mart., Eichler \& Urban, Fl. Bras. 14 (3): 339 (1885).

Árvores ou arvoretas 3-4,5 m alt. Ramos, folhas, bractéolas, hipanto e sépalas com indumento estrigoso. Folhas pecioladas, pecíolos 4-8 mm compr.; lâmina elíptica, base aguda, ápice agudo, margem inteira, 1-2 pares de nervuras basais, segundo par lateral tênue, confluente. Tirsos de dicásio, brácteas oblongas a lanceoladas; pedicelo 2-5 mm compr.; flores 5-meras, hipanto urceolado; sépalas caducas, triangulares, ápice agudo; pétalas roxas; 10 estames roxos, subisomórficos, filetes setoso-glandulosos, anteras subuladas, ápice atenuado, conectivo prolongado abaixo das tecas, apêndice ventral do conectivo bilobado, curto setoso-glanduloso; ápice do ovário e estilete seríceos. Cápsula.

Material selecionado: 1-IX-2011, fl. e fr., A.F.A. Versiane et al. 37 (HUFU).

Ocorre exclusivamente no interior da vereda. Floresce em setembro. Caracteriza-se pelo hábito arbóreo, hipanto glanduloso e filetes com tricomas glandulares. Assemelha-se a T. gracilis que também ocorre na área, porém esta apresenta hábito subarbustivo, hipanto adpresso-seríceo e filetes glabros.

26. Tibouchina gracilis (Bonpl.) Cogn., in Mart., Eichler \& Urban, Fl. bras. 14 (3): 386 (1885).

Subarbustos 0,5-1,3 m alt. Caule, folhas, brácteas, hipanto e sépalas adpresso-seríceos. Folhas pecioladas; pecíolos 2-8 mm compr.; lâmina elíptica a lanceolada, base obtusa a atenuada, ápice agudo a acuminado, margem crenulado-ciliada, 2 pares de nervuras basais. Tirsos de dicásios congestos, brácteas lanceoladas; flores 5-meras, pedicelo 1,5-6 mm compr., hipanto urceolado; sépalas persistentes, lanceoladas a triangulares, ápice agudo; pétalas arroxeadas; raramente alvas, 10 estames subisomórficos, filetes glabros, anteras subuladas, ápice atenuado, conectivo prolongado abaixo das tecas, apêndice ventral amarelo, raramente alvo, bilobado, estames antessépalos com anteras amarelas, raramente alvas, antepétalos com anteras amarelo-vináceas, raramente alvas; ápice do ovário seríceo, estilete glabro. Cápsula.

Material selecionado: 15-II-2011, fl., R. Romero et al. 8432 (HUFU).

Ocorre frequentemente na transição cerrado sentido restrito-vereda. Floresce de novembro a maio. Ver comentários em $T$. candolleana.

27. Trembleya parviflora (D. Don) Cogn., in Mart., Eichler \& Urban, Fl. bras. 14 (3): 127 (1883).

Arbustos ou arvoretas $0,7-1,7 \mathrm{~m}$ alt. Ramos, folhas, hipanto e sépalas glandulosos, com tricomas curto pedunculados. Folhas opostas, discolores, pecioladas, pecíolos 6-10 mm compr.; lâmina lanceolada, ápice acuminado, base atenuada, margem inteira, revoluta, 1 par de nervuras basais. Dicásios simples; brácteas lanceoladas a espatuladas, margem revoluta. Flores 5-meras, pediceladas, pedicelo 1-2 mm compr., hipanto oblongo-campanulado; sépalas subuladas, ápice agudo, margem inteira; pétalas alvas a alvorosadas, oblongas, ápice arredondado, margem inteira; 10 estames, dimórficos, conectivo prolongado abaixo das tecas, roxo, antera rostrada, rostro ca. $0,3 \mathrm{~mm}$ compr., anteras do ciclo antessépalo rosadas, apêndice ventral profundamente bilobado, do ciclo antepétalo amarelas, apêndice ventral levemente bilobado. Ovário 5-locular, glabro; estilete glabro. Cápsula arredondada, deiscente do ápice para a base.

Material selecionado: 22-X-1993, fl., R. Romero et al. 537 (HUFU).

Encontrada uma grande população próxima a áreas inundáveis, em solo arenoso. Floresce em junho, julho, agosto e outubro e frutifica em setembro e outubro. Distingue-se de Trembleya phlogiformis pelas folhas discolores de consistência cartácea e indumento glanduloso, constituído por tricomas glandulares curto-pedunculados.

28. Trembleya phlogiformis DC., Prodr. 3: 126 (1828).

Arbustos 0,5-2 m alt. Ramos, folhas, hipanto e sépalas híspido-glandulosos. Folhas opostas, concolores, pecioladas, pecíolos 2-3 mm compr.; lâmina lanceolada a oval-lanceolada, ápice agudo, base atenuada, margem serreada, 2 pares de nervuras basais. Dicásio simples; brácteas lanceoladas, margem serreada; Flores 5-meras, pediceladas, pedicelo 6-9 mm compr.; hipanto urceolado; sépalas subuladas, ápice agudo, com um tricoma setoso conspícuo; 
pétalas creme a alvas com estrias róseas, obovais, ápice acuminado; 10 estames, dimórficos, conectivo prolongado abaixo das tecas, anteras rostradas, rostro ca. 0,2 $\mathrm{mm}$ compr., anteras do ciclo antessépalo rosadas, apêndice ventral bilobado, anteras do ciclo antepétalo amarelas, apêndice ventral obtuso; ovário 5-locular, glabro; estilete glabro. Cápsula arredondada, deiscente do ápice para a base.

Material selecionado: 26-V-2011, fl., A.F.A. Versiane \& L.F. Bacci 14 (HUFU).

Ocorre frequentemente em campo úmido ou no interior da vereda em solo encharcado. Floresce de março a setembro. Caracterizada pelo indumento híspido-glanduloso, folhas verde-amareladas (em material seco) e pétalas creme a alvas, geralmente com estrias róseas.

\section{Considerações Finais}

Todas as espécies de Melastomataceae encontradas na Reserva do Clube Caça e Pesca Itoróró são nativas do Brasil, entretanto metade tem distribuição extra brasileira, ocorrendo, também, em outros países da América de Sul e/ou da América Central (Desmoscelis villosa, Leandra aurea, L. erostrata, Macairea radula, Miconia albicans, M. chamissois, M. fallax, M. ferruginata, M. rubiginosa, $M$. theizans, Rhynchanthera dichotoma, R. grandiflora, Siphanthera foliosa e Tibouchina gracilis) (Baumgratz 2016a; Baumgratz 2016b; Baumgratz et al. 2016b; Baumgratz \& Souza 2016; Goldenberg et al. 2013; Goldenberg \& Caddah 2016; Guimarães 2016; Romero 2016).

Lavoisiera glandiflora, Miconia leucocarpa, Microlicia cordata, M. fasciculata, M. helvola, M. polystemma, Siphanthera cordata, S. gracillima e Tibouchina candolleana são espécies endêmicas do Cerrado (Baumgratz et al. 2016a; Goldenberg et al. 2013; Goldenberg \& Caddah 2016; Guimarães 2016; Romero 2016; Romero \& Woodgyer 2016). Contudo, algumas apresentam distribuição mais restrita no bioma, como Microlicia cordata que ocorre somente na Bahia e em Minas Gerais (Romero \& Woodgyer 2016), enquanto outras são amplamente distribuídas, como é o caso de Miconia leucocarpa presente nos estados de Goiás, Mato Grosso do Sul, Minas Gerais, São Paulo e no Distrito Federal (Goldenberg et al. 2013; Goldenberg \& Caddah 2016).

A maioria das espécies ocorre, também, em outros biomas brasileiros. Desmoscelis villosa,
Macairea radula, Miconia albicans, Rhynchanthera dichotoma, $R$. grandiflora e Tibouchina gracilis são as únicas espécies que, além do Cerrado, também ocorrem em outros dois biomas, a última na Mata Atlântica e nos Pampas e as demais na Amazônia e Mata Atlântica (Baumgratz 2016a, Baumgratz 2016b, Baumgratz et al. 2016b, Goldenberg et al. 2013, Goldenberg \& Caddah 2016, Guimarães 2016). Algumas espécies apresentam ocorrência restrita ao Cerrado e a mais um bioma, na Mata Atlântica (Acisanthera variabilis, Cambessedesia hilariana, Leandra aurea, L. erostrata, Miconia chamissois, M. ligustroides, M. theizans, Trembleya parviflora e T. phlogiformis) (Baumgratz \& Souza 2016; Goldenberg et al. 2013; Goldenberg \& Caddah 2016; Kriebel \& Rocha 2016; Martins, Rodrigues \& SilvaGonçalves 2016; Romero 2016; Silva-Gonçalves et al. 2016) e na Amazônia (Miconia fallax, M. ferruginata, M. rubiginosa e Siphanthera foliosa) (Goldenberg et al. 2013; Goldenberg \& Caddah 2016; Romero 2016).

\section{Agradecimentos}

Os autores agradecem à Universidade Federal de Uberlândia e ao Herbário HUFU pela estrutura e disponibilização das exsicatas, aos funcionários do Clube Caça e Pesca Itoróró Uberlândia por permitir coletas na área e à FAPEMIG pelo auxílio concedido para apresentação dos dados preliminares em congresso.

\section{Literatura citada}

Alvarenga, P.E.F., Freitas, R.F. \& Augusto, S.C. 2008. Diversity of Euglossini (Hymenoptera: Apidae) in Cerrado areas of Triângulo Mineiro, MG. Bioscience 23: 30-37.

Apolinário, V.A.R. 1995. Levantamento fitossociológico das espécies arbóreas do cerrado (s.s.) do Clube Caça e Pesca Itororó de Uberlândia-MG. Monografia de Bacharelado, Universidade Federal de Uberlândia, Uberlândia.

Apolinário, V.A.R. \& Schiavini, I. 2002. Levantamento Fitossociológico de espécies arbóreas de cerrado (strictu sensu) em Uberlândia-Minas Gerais. B. Herb. Ezechias Paulo Heringer 10: 57-75.

Araújo, F.P., Farias, Y.E.F. \& Oliveira, P.E. 2011. Biologia floral e visitantes de Gaylussacia brasiliensis (Spr.) Meissner (Ericaceae) - uma espécie com anteras poricidas polinizada por beija-flores. Acta Botanica Brasilica 25: 387-394. 
Araújo, F.P. \& Oliveira, P.E. 2007. Biologia floral de Costus spiralis (Jacq.) Roscoe (Costaceae) e mecanismos para evitar a autopolinização. Revista Brasileira de Botânica 30: 61-70.

Araújo, G.M., Barbosa, A.A.A., Arantes, A.A. \& Amaral, A.F. 2002. Composição florística de veredas no Município de Uberlândia, MG. Revista Brasileira de Botânica 25: 475-493.

Augusto, S.C. \& Garófalo, C.A. 2007. Nidificação de Euglossa melanotricha Moure (Hymenoptera: Apidae) no Solo do Cerrado. Netropical Entomology 36: 153-156.

Bacci, L.F., Versiane, A.F.A. \& Romero, R. 2016. Melastomataceae da Reserva do Clube Caça e Pesca Itoróró Uberlândia, Minas Gerais, Brasil. In: R. Foster, J. Philipp \& T. Wachter (eds.). Rapid Color Guide. The Field Museum of Chicago. Disponível em: http:// fieldguides.fieldmuseum.org/guides/guide/392 (acesso em 20-1-2016).

Baumgratz, J.F.A. 2016a. Desmoscelis in Lista de Espécies da Flora do Brasil. Jardim Botânico do Rio de Janeiro. Disponível em http://floradobrasil.jbrj.gov.br/jabot/ floradobrasil/FB9460 (acesso em 18-I-2016).

Baumgratz, J.F.A. 2016b. Macairea in Lista de Espécies da Flora do Brasil. Jardim Botânico do Rio de Janeiro. Disponível em http://floradobrasil.jbrj.gov.br/jabot/ floradobrasil/FB19634 (acesso em 18-I-2016).

Baumgratz, J.F.A., Martins, A.B. \& Rodrigues, K.F. 2016a. Lavoisiera in Lista de Espécies da Flora do Brasil. Jardim Botânico do Rio de Janeiro. Disponível em http://floradobrasil.jbrj.gov.br/jabot/floradobrasil/ FB9492 (acesso em 18-I-2016).

Baumgratz, J.F.A., Martins, A.B. \& Rodrigues, K.F. 2016b. Rhynchanthera in Lista de Espécies da Flora do Brasil. Jardim Botânico do Rio de Janeiro. Disponivel em http://floradobrasil.jbrj.gov.br/jabot/floradobrasil/ FB9864 (acesso em 18-I-2016).

Baumgratz, J.F.A., Souza, M.L.D.R. 2016. Leandra in Lista de Espécies da Flora do Brasil. Jardim Botânico do Rio de Janeiro. Disponível em http://floradobrasil. jbrj.gov.br/jabot/floradobrasil/FB9506 (acesso em 18-I-2016).

Baumgratz, J.F.A., Caddah, M.K., Chiavegatto, B., Goldenberg, R., Guimarães, P.J.F., Koschnitzke, C., Kriebel, R., Lima, L.F.G., Martins, A.B., Michelangeli, F.A., Reginato, M., Rocha, M.J.R., Rodrigues, K.F., Romero, R., Rosa, P., SilvaGolçalves, K.C., Souza, M.L.D.R. \& Woodgyer, E. 2016. Melastomataceae in Lista de Espécies da Flora do Brasil. Jardim Botânico do Rio de Janeiro. Disponível em http://floradobrasil.jbrl.gov.br/jabot//floradobrasil/ FB161 (acesso em 20-VII-2016).

Boaventura, R.S. 1978. Contribuição ao estudo sobre a evolução as veredas. In: $2^{\circ}$ Plano de Desenvolvimento Integrado do Noroeste Mineiro. CETEC, Belo Horizonte, Informe Técnico, v. 1, n. 1, pp. 111-112.
Cardoso, G.L. \& Lomônaco, C. 2003. Variações fenotípicas e potencial plástico de Eugenia calycina Cambess (Myrtaceae) em uma área de transição cerradovereda. Revista Brasileira de Botânica 26: 131-140.

Carvalho, M.P., Santana, D.G. \& Ranal, M.A. 2005. Emergência de plântulas de Anacardium humile A. St.-Hil. (Anacardiaceae) avaliada por meio de amostras pequenas. Revista Brasileira de Botânica 28: 627-633.

Consolaro, H., Silva, E.B. \& Oliveira, P.E. 2005. Variação floral e biologia reprodutiva de Manettia cordifolia Mart. (Rubiaceae). Revista Brasileira de Botânica 28: 85-94.

Del-Claro, K., Santos, J.C. \& Junior, A.D.S. 2002. Etograma da formiga arborícola Cephalotes pusillus (Klug, 1824) (Formicidae: Myrmicinae). Revista de Etologia 4: 31-40.

Eiten, G. 2001. Vegetação natural do Distrito Federal. 1 ed. SEBRAE, Brasília.

Fuzeto, A.P. \& Lomônaco, C. 2000. Potencial plástico de Cabralea canjerana subsp. polytricha (Adr. Juss.) Penn. (Meliaceae) e seu papel na formação de ecótipos em áreas de cerrado e vereda, Uberlândia, MG. Revista Brasileira de Botânica 23: 169-176.

Goldenberg, R., Almeda, F., Caddah, M.K., Martins, A.B., Meirelles, J., Michelangeli, F.A. \& Weiss, M. 2013. Nomenclator botanicus for the neotropical genus Miconia (Melastomataceae: Miconieae). Phytotaxa 106: 1-171.

Goldenberg, R. \& Caddah, M.K. 2016. Miconia in Lista de Espécies da Flora do Brasil. Jardim Botânico do Rio de Janeiro. Disponível em http://floradobrasil.jbrj.gov. br/jabot/floradobrasil/FB9666 (acesso em 18-I-2016).

Goldenberg, R. \& Martin, C.V. 2008. Taxonomic Notes on South American Miconia (Melatomataceae). Harvard Papers in Botany 30: 223-227.

Guimarães, P.J.F. 2016. Tibouchina in Lista de Espécies da Flora do Brasil. Jardim Botânico do Rio de Janeiro. Disponível em http://floradobrasil.jbrj.gov.br/jabot/ floradobrasil/FB9876 (acesso em 18-I-2016).

Instituto Brasileiro do Meio Ambiente (IBAMA). 1992. Lista Oficial da Flora Brasileira Ameaçada de Extinção. Portaria 37-N.

Klink, C.A. \& Machado, R.B. 2005. A conservação do Cerrado brasileiro. Megadiversidade 1: 147-155.

Kriebel, R. \& Rocha, M.J.R. 2016. Acisanthera in Lista de Espécies da Flora do Brasil. Jardim Botânico do Rio de Janeiro. Disponível em http://floradobrasil.jbrj.gov. br/jabot/floradobrasil/FB9395 (acesso em 20-I-2016).

Martins, A.B., Rodrigues, K.F. \& Silva-Gonçalves, K.C. 2016. Trembleya in Lista de Espécies da Flora do Brasil. Jardim Botânico do Rio de Janeiro. Disponível em http://floradobrasil.jbrj.gov.br/jabot/floradobrasil/ FB9979 (acesso em 20-I-2016).

Mendonça, R.C., Felfili, J.M., Walter, B.M.T., Silva Júnior, M.C., Rezende, A.V., Filgueiras, T.S. \& Nogueira, P.E. 2008. Flora vascular do Cerrado. In: S.M. Sano \& S.P. Almeida (eds.). Cerrado: ecologia e flora. Embrapa Cerrados, Planaltina, pp. 289-556. 
Myers, N., Mittermeier, R.A., Mittermeier, C.G., Fonseca, G.A.B. \& Kent, J. 2000. Biodiversity hotspots for conservation priorities. Nature 403: 853-858.

Radford,A.E., Dickson, W.C., Massey, J.R. \& Bell, C.R. 1974. Vascular Plants Systematics. New York, Harper \& Row.

Renner, S.S. 1990. A revision of Rhynchanthera (Melastomataceae). Nordic Journal of Botany 9: 601-630.

Ribeiro, J.F. \& Walter, B.M.T. 2008. As principais fitofisionomias do Cerrado. In: S.M. Sano, S.P. Almeida \& J.F. Ribeiro (eds.). Cerrado: ecologia e flora. Embrapa Cerrados, Planaltina, pp. 87-166.

Rocha-Filho, L.C. \& Lomônaco, C. 2006. Variações fenotípicas em subpopulações de Davilla elliptica A. St.-Hil. (Dilleniaceae) e Byrsonima intermedia A. Juss. (Malpighiaceae) em uma área de transição cerradovereda. Acta botanica brasilica 20: 719-725.

Romero, R. 1997. O gênero Siphanthera Pohl. ex DC. (Melastomataceae) no estado de Minas Gerais. Revista Brasileira de Botânica 20: 175-183.

Romero, R. 2000. A new species of Microlicia (Melastomataceae) from Brazil. Brittonia 52: 142-144.

Romero, R. 2016. Siphanthera in Lista de Espécies da Flora do Brasil. Jardim Botânico do Rio de Janeiro. Disponível em http://floradobrasil.jbrj.gov.br/jabot/ floradobrasil/FB9870 (acesso em 18-I-2016).

\section{Lista de exsicatas}

Alice, F.A. 10 (26). Amaral, A.F. 22 (2); 23 (19); 1415 (15); 1416 (7); 1417 (5); 1420 (15); 1895 (2); s.n. HUFU 22616 (2); s.n. HUFU 23458 (3); s.n. HUFU 27777 (2). Arantes, A.A. 15 (21); 19 (28); 20 (3); 26 (9); 35 (15); 49 (14); 67 (17); 77 (9); 165 (13); 179 (9); 1550 (9); 1558 (9); 1620 (13); 1755 (1); 1775 (21); 1825 (14); 1827 (26); 1828 (19); 1829 (28); 1856 (9). Araújo, G.M. 1755 (1); 1756 (28); 1805 (17); 1806 (10); 1807 (7); 1830 (25); 1831 (28); 2034 (5); 2035 (15); 2036(2); 2083 (26); 2084 (18); 2085 (26); 2087 (9); 2464 (19); 2552 (14); 2567 (19); 2677 (7); 2981 (26); 3141 (18); 3142 (22); 3143 (26); s.n. s.n. HUFU 16747 (3); HUFU 18067 (2); s.n. HUFU 20053 (3); s.n. HUFU 20054 (15); s.n. HUFU 20057 (5); s.n. HUFU 20093 (2); s.n. HUFU 45547 (21). Arruda, R. 31 (11). Azevedo, F.F.A. 3 (26). Bacci, L.F. 16 (8); 17 (4); 18 (5); 19 (6); 20 (17); 21 (18); 22 (1); 23 (20); 24 (19). Barbosa, A.A.A. 1147 (17); 1412 (26); 1413 (19); 1414 (26); 1902 (2); 1915 (28); 1962 (2); 2328 (25); 2452 (2); 3267 (22); 3268 (28); 3286 (3); 3287 (19); 3400 (19); 3401 (26); s.n. HUFU 16978 (3); s.n. HUFU 17842 (3); s.n. HUFU 19373 (21); s.n. HUFU 20916 (3); s.n. HUFU 31781 (3); s.n. HUFU 32329 (2); s.n. HUFU 32331 (8); s.n. HUFU 32394 (3); s.n. HUFU 32402 (3); s.n. HUFU 33710 (22); s.n.
Romero, R. \& Martins, A.B. 2002. A família Melastomataceae no Parque Nacional da Serra da Canastra, Minas Gerais, Brasil. Dissertação de Mestrado. Universidade Estadual de Campinas, Campinas.

Romero, R. \&Woodgyer, E. 2016. Microlicia in Lista de Espécies da Flora do Brasil. Jardim Botânico do Rio de Janeiro. Disponível em http://floradobrasil.jbrj.gov. br/jabot/floradobrasil/FB9782 (acesso em 18-I-2016).

Santos, M.L., Afonso, A.P. \& Oliveira, P.E. 1997. Biologia floral de Vochysia cinnamomea Pohl. (Vochysiaceae) em cerrados do Triângulo Mineiro, MG. Revista Brasileira de Botânica 20: 127-132.

Silva-Gonçalves, K.C., Martins, A.B. \& Rodrigues, K.F. 2016. Cambessedesia in Lista de Espécies da Flora do Brasil. Jardim Botânico do Rio de Janeiro. Disponível em http://floradobrasil.jbrj.gov.br/jabot/floradobrasil/ FB9432 (acesso em 20-I-2016).

Thiers, B. 2015. Index herbariorum: a global directory of public herbaria and associated staff. New York Botanical Garden's Virtual Herbarium. Disponível em http:// sweetgum.nybg.org/ih/ (acesso em 20-I-2016).

Wurdack, J.J. 1986. Atlas of hair for neotropical Melastomataceae. Smithsonian Contributions to Botany, Washington.

HUFU 33716 (2); s.n. HUFU 33720 (21); s.n. HUFU 42391 (21); s.n. HUFU 45467 (2); s.n. HUFU 57841 (8). Basílio, R. 3 (19). Bordon, N. s.n. HUFU 50481 (21). Bruno, C.G.C. 9 (3). Castro, W.S. 2 (19); 4 (2). Castro, M. 95 (8). Costa, L. 1 (10); 10 (2); 11 (26). Cunha, K. 3 (17); 6 (10). Faria, P. s.n. HUFU 19374 (3). Fragola, L.J. 3 (10). Franca, R.O. 5 (10). Leenza, E.O. 97 (10); 254 (10); 278 (14); 313 (26); 373 (26); 409 (13). Lima, C.C.A. 7 (2). Maciel, A.A. 8 (26). Meirelles, C.J. 6 (21); 9 (19). Melazzo, A.F.O. 34 (10). Nakajima, J.N. 115 (23); 213 (13); 233 (19); 234 (19); 235 (26); 251 (4). Oliveira, A.C.H. s.n. HUFU 33711 (3). Oliveira, A.P.A. 1 (14); 60 (10); 105 (10); 106 (10); s.n. HUFU 41306 (8). Oliveira, G.C. 16 (26); 17 (18); 298 (26); 299 (2); 382 (28); 542 (26); 543 (3); 544 (17); 545 (21); 546 (22); 632 (9); 635 (9); 636 (28); 661 (21); 804 (3); 807 (28); 816 (19); 843 (3); 953 (3); 954 (9); 955 (17); 956 (28); 972 (27); 1093 (19); 1094 (28); 1095 (21); 1665 (26); 1666 (15); 2009 (26); 2010 (2); 2052 (19); 2053 (17); 2350 (2); 2370 (26); 2425 (18); 2537 (20); 2538 (21); 2614 (24); 2629 (19); 2692 (17). Paula, A.T. de 12 (3). Pereira, B.B. 1 (2); 2 (10); 3 (19). Prado, P.M.M. s.n. HUFU 19115 (4). Rezende, A.R. 168 (10). Rocha, F.A. s.n. HUFU 36831 (2). Rocha, M.J.R. 728 (23); 729 (1); 730 (20); 731 (21); 732 (3); 733 (9); 734 (14); 934 (19); 936 (16); 938 (18). Rodrigues, C.M. s.n. HUFU 37004 
(3). Romero, R. 107 (3); 500 (15); 520 (13); 521 (5); 522 (14); 523 (13); 532 (13); 534 (19); 537 (27); 538 (15); 542 (7); 544 (14); 545 (19); 546 (6); 547 (15); 548 (15); 549 (10); 552 (2); 558 (2); 560 (19); 774 (21); 777 (26); 781 (10); 782 (19); 799 (12); 998 (3); 999 (24); 1000 (22); 1002 (17); 1005 (28); 1006 (19); 1007 (12); 1011 (24); 1012 (3); 1014 (21); 1015 (28); 1097 (23); 1416 (2); 1806 (26); 1816 (19); 1829 (19); 1831 (26); 2101 (4); 2103 (22); 2104 (24); 2105 (26); 2107 (3); 2324 (3); 2329 (4); 2330 (21); 2340 (10); 2341 (24); 2342 (28); 2343 (19); 2344 (19); 2345 (19); 2346 (8); 2347 (19); 3019 (10); 3020 (10); 3021 (27); 3022 (10); 3023 (10); 4949 (13); 5897 (21); 7059 (16); 8206 (19); 8208 (9); 8209 (28); 8432 (26); 8433 (18); 8434 (9); 8435 (2); 8687 (19); 8688 (16); 8689 (18);
8691 (28); 8692 (17). Santos, A.O.R. 5 (19); 6 (6); 12 (10). Silva, C.I. 46 (21). Silva, D.M.S. 6 (10). Silva, M.R. 7 (10); 8 (2); s.n. 32330 (3). Simão, D.G. 166 (6); 167 (15); 170 (14); 171 (10); 202 (3); 203 (9); 204 (9); 205 (20); 206 (20); 207 (26); 208 (6); 209 (6); 213 (3); 214 (26); 215 (28). Souza, M.R. 8 (2). Trindade, N. s.n. HUFU 46577 (8). Versiane, A.F.A. 1 (16); 3 (21); 4 (3); 7 (28); 8b (16); 9 (16); 11 (14); 12 (19); 13 (3); 14 (28); 15 (9); 16 (15); 17 (17); 18 (22); 21 (14); 22 (16); 23 (16); 24 (27); 25 (19); 26 (17); 27 (16); 28 (19); 30 (18); 31 (28); 32 (18); 35 (23); 37 (35); 38 (20); 40 (18); 41 (10); 42 (8); 44 (5); 45 (7); 55 (10); 56 (19); 58 (15); 59 (17); 67 (18); 240 (27); 241 (23); 242 (1); 244 (18); 246 (16). Via do Pico, G. 77 (4).Vieira, F. s.n. HUFU 59512 (2). 